\title{
Prospects for the use of unmodified antisense oligonucleotides in the regulation of the synthesis of secondary metabolites of essential oil plants \\ Puzanova E.V.
}

FSBSI «Research Institute of Agriculture of Crimea», Simferopol, Crimea E-mail: 17obruchka@mail.ru

Key message. A scheme and basic principles for the use of unmodified antisense oligonucleotides in the agricultural sector as a regulator of the synthesis of secondary metabolites of essential oil plants are developed.

Keywords: antisense technologies, secondary metabolites, essential oil plants, synthesis regulation.

Regulation of the synthesis of secondary metabolites with the help of unmodified antisense oligonucleotides (uASO) is a new direction in Plant Biochemistry and Biotechnology, which was initiated by Oberemok et al. (2019). The use of uASO will allow the component composition of essential oil to be changed selectively, according to the needs of different industries. The study is aimed at changing the component composition of essential oil using uASO. The method is based on the suppression of the expression of genes of various synthases by short DNA fragments that block the translation process of one or another part of the uASO gene. Therefore, the duplex DNA-mRNA is formed by binding. This duplex prevents biosynthesis of protein, in particular of enzymes involved in biochemical cascades of the synthesis of components of essential oils, either through steric blocking or splitting by RNAse-H. The use of DNA fragments is justified by absence of undesirable effects. For example, major RNA fragments are quite long and tend to decompose into small interfering RNAs, which can interact with a wide range of non-target location. Safety also causes the refusal to modify fragments of the active substance, namely to attach various groups to one of the ends, and to change nitrogenous bases and sugar-phosphate backbone. Following a series of tests with different essential oil plants and proving the effectiveness of this method for most cultures, it will become possible to adjust the component composition for pharmacology, cosmetology and perfumery usage. Developments in this direction are of great importance for agriculture for a number of reasons, namely because of low consumption of the active substance of the specimen; unlimited expiration date (subject to storage conditions); high rate of reaching target; uASOs are safe for the environment and all non-target organisms; uASOs that have not reached their unique target are destroyed by cell nucleases; synthesis of nucleic acids is getting cheaper every year. At the moment, the method has already been successfully tested on pepper mint; lavender, thyme, savory and basil are being worked on.

\section{Перспективы использования немодифицированных антисмысловых олигонуклеотидов в регуляции синтеза вторичных метаболитов эфиромасличных растений Пузанова Е.В.}

ФГБУН «Научно-исследовательский институт сельского хозяйства Крыма», Симферополь, Крым

\begin{abstract}
Аннотация. Разрабатывается схема и основные принципы использования немодифицированных антисмысловых олигонуклеотидов в отрасли сельского хозяства в качестве регулятора синтеза вторичных метаболитов эфиромасличных растений.
\end{abstract}

Ключевые слова: антисмысловые технологии, вторичные метаболиты, эфиромасличные растения, управление синтезом.

Управление синтезом вторичных метаболитов с помощью немодифицированных антисмысловых олигонуклеотидов $($ нАCO) - новое направление в биохимии и биотехнологии растений, начало которому положила работа Оберемка и соавторов (2019). Использование нАСО позволит избирательно изменять компонентный состав эфирного масла под потребности разных отраслей производства. Целью данного исследования является изменение компонентного состава эфирного масла с помощью нАСО. В основе метода лежит подавление экспрессии генов различных синтаз короткими фрагментами ДНК, блокирующими процесс трансляции того или иного участка гена. нАСО, связываясь с мРНК образует дуплекс «ДНК-мРНК», который либо путем стерического блокирования, либо путем расщепления РНКазойН препятствует биосинтезу белка, в частности, ферментов участвующих в биохимических каскадах синтеза компонентов эфирных масел. Применение ДНК-фрагментов оправдано отсутсвием нежелательных эффектов. Так, например, известные РНК-фрагменты, имеющие большую длину, имеют свойство распадаться на малые интерферирующие РНК, которые могут взаимодействовать с большим спектром нецелевых объектов. Безопасность обуславливает и отказ от модификации фрагментов активного вещества: присоединения различных групп к одному из концов, изменения самих азотистых оснований и сахаро-фосфатного остова. После проведения ряда испытаний с разными эфиромасличными растениями и доказательства эффективности данного метода для большинства культур станет возможным подстраивать компонентный состав под использование в фармакологии, косметологии и парфюмерии. Разработки в этом направлении имеют высокую значимость для сельского хозяйства по ряду причин: малый расход действующего вещества препарата; неограниченный срок годности (при соблюдении условий хранения); высокая таргетность; нАСО безопасны для окружающей среды и всех нецелевых организмов; нАСО, не достигшие своей уникальной мишени, разрушаются нуклеазами клетки; синтез нуклеиновых кислот удешевляется с каждым годом. На данный момент метод уже успешно апробирован на перечной мяте, ведутся работы на лаванде, тимьяне, чабере и базилике. 